\title{
CONSUMER CLASS ACTIONS UNDER THE UNIFORM DECEPTIVE TRADE PRACTICES ACT
}

\begin{abstract}
RICHARD F. DOLE, JR.*
The Uniform Deceptive Trade Practices Act, presently in force in eight states, makes a private injunctive remedy available to "persons likely to be damaged" by misleading advertising, false disparagement, trade symbol infringement and other deceptive trade practices. This article explores the utility of the Uniform Act to individual consumers, and to groups of consumers. The procedural prerequisites of class actions under both the new and old versions of Rule 23 are considered in detail, and it is concluded that consumer class actions under the Uniform Act can provide an effective remedy for widespread and systematic consumer protection.
\end{abstract}

$T^{2}$ HE WAR on Poverty has focused increasing interest on consumer law-the legal rights, privileges, immunities, powers, and duties of persons who obtain commercial goods, services, realty, or intangibles. ${ }^{1}$ The National lnstitute for Education in Law and Poverty, which serves a continuing legal education function for Office of Economic Opportunity Neighborhood Legal Services Attorneys, has, for example, recently published a Handbook on Consumer Ldw,

* Associate Professor, University of lowa College of Law; LL.B. 1961, LL.M. 1963, Cornell; S.J.D. 1966, University of Michigan; Consultant, Special Committee on Unfair Competition, National Conference of Commissioners on Uniform State Laws 1962-65. This article does not necessarily reflect the views of the National Conference of Commissioners on Uniform State Laws.

The author is presently of counsel in a consumer class action under the Uniform Deceptive Trade Practices Act: Holstein v. Montgomery Ward \& Co., No. 68 CH 275 (1ll. Cir. Ct., Cook Cty. 1968).

' Consumer law in this sense is the economic aspect of Edmond Cahn's consumer perspective of law: "Some consumers need bread; others need Shakespeare; others need their rightful place in the national society-what they all need is processors of law who will consider the people's needs more significant than administrative convenience." Cahn, Law in the Consumer Perspective, 112 U. PA. L. Rev. 1, 13 (1963).

2 National lnstitute for Education in Law and Poverty, Handbook on Consumer LAw (2d ed. 1968). The Neighborhood Legal Services Program was established by the Office 
and several law schools have introduced consumer law courses or seminars. ${ }^{3}$ This stress on consumer law by poverty lawyers is readily understandable. The Kerner Commission disclosed that unfair consumer sales and credit practices are one of the twelve major sources of discontent in urban ghettos. ${ }^{4}$ Moreover, even in that hopefully not-too-distant future when the War on Poverty is approaching victory, consumer law problems will remain. Indeed, the various poverty programs can be viewed primarily as endeavors to make poor persons more equal consumers. ${ }^{s}$

An even more recent phenomenon is the use of consumer class actions or "representative suits" 6 by poverty lawyers. " A class action is, of course, an action in which certain members of a group with similar legal claims or defenses represent the entire group in litigation. Class actions have hitherto served a yeoman function as a tool for securing civil rights and civil liberties through the desegregation of school systems, ${ }^{8}$ the reapportionment of legislatures, ${ }^{9}$ and the challenging of welfare eligibility rules. ${ }^{10}$ The adaptation of class actions to consumer law issues is attributable in part to the enlistment of a number of seasoned civil rights litigators in the War on Poverty." However, the emergence of consumer class actions is fully warranted by the strategic advantages of such actions.

A class action responds to group injuries involving small amounts of individual damage by enabling representatives of a class to place

of Economic Opportunity in 1965 in an effort to provide legal services to the poor and to stimulate the poor to engage in community action. The program was inspired by Cahn \& Cahn, The War on Poverty: A Civilian Perspective, 73 YALE L.J. 1317 (1964). The National lnstitute for Education in Law and Poverty was established in 1967. Note, Beyond the Neighborhood Office-OEO's Special Grants in Legal Services, 56 GEO. L.J. 742, 764-66 (1968).

${ }^{3}$ E.g.. Cornell Law School announcenent 64 (1968-69); Duke Law School Bulletin 5 (1968); Rutgers School of LaW--Newark ANnOuncement 23 (1968-69). The University of lowa College of Law offers a course in Unfair Competition and Consumer Protection taught by the author.

4 Report of the National Advisory Commission on Civil Disorders 139-40 (1968).

' Viles, The War on Poverty: What Can Lawyers (Being Hunan) Do?, 53 lowa L. Rev, 122, 161-62 (1967).

- Z. Chafee, Some Problems of Equity, chs. VI \& V11 (1950).

${ }^{7}$ E.g., Russell v. Coburn Corp., No. 6338/68 (N.Y. Sup. Ct., Bronx Cty. 1968); Wainwright v. Young, No. $68 \mathrm{CH} 2320$ (1ll. Cir. Ct., Cook Cty. 1968).

${ }^{s}$ E.g.. Brown v. Board of Education, 347 U.S. 473 (1954).

' E.g., Baker v. Carr, 369 U.S. 186 (1962).

${ }^{10}$ E.g., King v. Smith, 392 U.S. 309 (1968).

"See, e.g.. Russell v. Coburn Corp., No. 6338/68 (N.Y. Sup. Ct., Bronx Cty. 1968) (consumer class action in which the plaintiffs are represented by the NAACP Lcgal Defense and Education Fund, lnc.). 
the entire group injury in issue. ${ }^{12}$ This escalatory effect of a class action justifies the expenditure of more time and money by the class representatives in pressing their claims. ${ }^{13}$ it also renders the claims more likely to receive careful judicial processing. For example, a judge will inevitably take more seriously a claim that all of a particular metropolitan taxicab company's customers have been overcharged than an overcharge claim by a single customer. ${ }^{14}$ Moreover, because of its size, a claim on behalf of a class is far more likely to meet the jurisdictional requirements of courts of general jurisdiction. ${ }^{15}$

Another advantage is the economic, psychological, and procedural pressure which a class action puts on a defendant. ${ }^{16}$ The economic pressure derives both from the legal economies of scale which accrue to the representatives of a plaintiff-class and from the potential consequences for a class opponent. The psychological pressure derives from the notoriety that often attaches to a class action. The visibility, publicity, and public reaction aroused by a class action can produce results that are as significant as the ultimate outcome of the action. ${ }^{17}$ Finally, the procedural pressure derives from the number of individual transactions which can be placed in issue by representatives of the class, and from the barriers to settling a class action. Poverty lawyers have seen some of their best opportunities to establish consumer-oriented precedents destroyed by well-timed offers of settlement with the particular consumer-plaintiffs. ${ }^{18}$ How-

12 Kalven and Rosenfield have described the social significance of the class action device as follows: "Modern society seems increasingly to expose men to such group injuries for which individually they are in a poor position to seek legal redress, either because they do not know enough or because such redress is disproportionately expensive. If each is left to assert his rights alone if and when he can, there will at best be a random and fragmentary enforcement if there is any at all. This result is not only unfortunate in the particular case, but it will operate seriously to impair the deterrent effect of the sanctions which underlie much contemporary law." Kalven \& Rosenfield, The Contemporary Function of the Class Suit, 8 U. CHI. L. REv. 684, 686 (1941).

13 Note, Parties Plaintiff in Civil Rights Litigation, 68 Colum. L. Rev. 693, 901 (1968).

"See Daar v. Yellow Cab Co., 67 Cal. 2d 695, 433 P.2d 732, 63 Cal. Rptr. 724 (1967) (In Bank).

is See Proceedings of the Harvard Conference on Law and Poverty 40-43 (1967).

${ }^{16}$ Starrs, The Consunter Class Action: Considerations of Equity and Procedure in NATIONAL INSTITUTE fOR EDUCATION IN LAW AND POVERTY, HaNDBOoK ON CONSUMER LAW 109-11 (2d ed. 1968).

${ }^{17}$ Id. at 109.

${ }^{15}$ See Note, Neighborhood Law Offices: The New Wave in Legal Services for the Poor. 80 HARV. L. Rev. 805, 814-15 (1967). 
ever, the complexity of settlement negotiations with multiple class representatives ${ }^{19}$ and the requirement in many jurisdictions of court approval of any compromise of a class action ${ }^{20}$ coalesce to make settlement of class actions an imposing proposition.

In anticipation of the profound influence consumer class actions will have upon the development of consumer law and poverty law in general, this article explores the feasibility of such class actions under the Uniform Deceptive Trade Practices Act. In the opinion of the author, consumer class actions are both a feasible and a desirable means of achieving the objectives of the Uniform Act.

\section{An Outline of the Uniform Deceptive Trade Practices Act}

The Uniform Deceptive Trade Practices Act, ${ }^{21}$ which is presently in force in eight states, ${ }^{22}$ provides a private injunctive remedy to persons "likely to be damaged" by deceptive trade practices. ${ }^{23}$ Section 2(a) of the Uniform Act contains both a general condemnation of deceptive commercial conduct in section 2(a)(12), and a series of

${ }^{19}$ See Johnson, A Conservative Rationale for the Legal Services Program, 70 W. VA. L. REv. 350, 355-56 (1968).

${ }^{20}$ E.g., Fed. R. Civ. P. 23(e); Ill. ANN. Stat. ch. 110, § 52.1 (Smith-Hurd 1956).

21 The Uniform Act was initially approved by the Commissioners on Uniform State Laws and the American Bar Association House of Delegates in 1964. HANDBOOK OF THE NATIONAL Conference of Commissioners on Uniform State Laws 131-32 (1964) [hereinafter cited as HANDBOOK]; 89 A.B.A. REP. 405 (1964). The Commissioners subsequently revised $\S 3(\mathrm{~b})$ of the act, which deals with allowance of costs and attorneys' fees, in response to a resolution by the ABA Section of Patent, Trademark, and Copyright Law. ABA PATENT, Trademark, AND Copyright Law Section 54-56, 64-66 (1965); 1966 HaNdbooK 90; 91 A.B.A. ReP. 357 (1966). The current version of the act, which is officially known as the Revised Uniform Deceptive Trade Practices Act, appears in 1966 HANDBooK 306-315 [hereinafter the current version of the act will be cited as UNIFORM ACT]. The original version of the act can be found in 9A Uniform Laws Ann. (Supp. 1967) and S. Oppenheim, Cases on Unfaik Trade PRACTICES 744 (2d ed. 1965).

${ }^{22}$ Conn. Gen. Stat. AnN. $\$ \S 42-115$ (c)-(f) (Supp. 1968); Del. Code ANN. tit. 6, §§ 2531-37 (Supp. 1966); Fla. STAT. ANN. $\$ \S 817.69-.75$ (Supp. 1968); GA. Code ANN. §§ (Supp. (1968); Idaho Code ANN. $\$ \S 48-601$ to $48-606$ (Supp. 1967); ILl. ANN. Stat. clı. 1211/2, $\$ 3311-18$ (Smith-Hurd Supp. 1967); N.M. STAT. ANN. \$\$ 49-15-1 to 49-15-14 (Supp. 1967); OKLA. Stat. AnN. tit. 78, $\S \S 51-55$ (Supp. 1967). The Connectieut, New Mexico, and Oklahoma enactments contain deviations from the recommended version of the act. E.g., Merill, Oklahoma and the National Conference of Commissioners on Uniform State Laws, 1965, 36 J. OKLA. B. Ass'N 2205-08 (1965). Commentary on the Uniform Act includes Dole, Merchant and Consumer Protection: The New York Approach to the Regulation of Deceptive Trade Practices, 53 CoRnell L. Rev. 749 (1968); Dole, The Uniform Deceptive Trade Practices Act: Another Step Toward a National Law of Unfair Trade Practices, 51 MiNN. L. Rev. 1005 (1967); Dole, Merchant and Consumer Protection: The Uniform Deceptive Trade Practices $A c t, 76$ YAlE L.J. 485 (1967).

" UNIFORM ACT $\$ 3($ a). 
specific subsections characterizing misleading advertising, false disparagement, and trade symbol infringement as deceptive trade practices. ${ }^{24}$ Sections $2(b)^{25}$ and $3(a)^{26}$ amplify section 2 (a) with

${ }^{24}$ A person engages in a deceptive trade practice when, in the course of his business, vocation, or occupation, he (1) passes off goods or services as those of another; (2) causes likelihood of confusion or of misunderstanding as to the source, sponsorship, approval or certification of goods or services; (3) causes likelihood of confusion or of misunderstanding as to affiliation, conncction, or association with, or certification by another; (4) uses deceptive representations or designations of geographic origin in connection with goods or services; (5) represents that goods or services have sponsorship, approval, characteristics, ingredients, uses, benefits, or quantities that they do not have or that a person has a sponsorship, approval, status, affiliation, or connection that he does not have; (6) represents that goods are original or new if they are deteriorated, altered, reconditioned, reclaimed, used, or second-hand; (7) represents that goods or services are of a particular standard, quality, or grade, or that goods are of a particular style or model, if they are of another; (8) disparages the goods, services, or business of another by false or misleading misrepresentation of fact; (9) advertises goods or services with intent not to sell them as advertised; (10) advertises goods or services with intent not to supply reasonably expectable public demand, unless the advertisement discloses a limitation of quantity; (II) makes false or misleading statements of fact concerning the reasons for, existence of, or amounts of price reductions; (12) or engages in any other conduct which similarly creates a likelihood of confusion or of misunderstanding. UNIFORM ACT $\$ 2(a)$.

Deceptive advertising consists of the dissemination of misleading factual statements concerning the product, service, or business of the disseminator. See Ely-Norris Safe Co. v. Mosler Safe Co., 7 F.2d 603, 604 (2d Cir. 1925), rev'd on other grounds, 273 U.S. 132 (1927). In Lower Main Street Merchants Ass'n v. Paul Geller \& Co., 67 N.J. Super. 514, I7I A.2d 2I (Ch. 1961), for instance, competitors were declared to be entitled to an injunction against a continuous "going out of business" sale conducted by a retail men's clothing store.

False disparagement involves the unprivileged publication of false, injurious statements about the product, service, or business of another. Prosser, Injurious Falsehood: The Basis of Liability, 59 Colum. L. REv. 425 (1959). False disparagement is also known as injurious falsehood, slander of goods, and trade libel. Id. Thus, in H.E. Allen Mfg. Co. v. Smith, 224 App. Div. 187, 229 N.Y.S. 692 (1928), a New York appellate court approved an injunction against the distribution of spurious United States Department of Agriculture documents that falsely indicated that the plaintiff's fly spray had been condemned by the government. False statements that impugn the integrity of credit of a business also constitute actionable defamation. See Marlin Fire Ärms Co. v. Shields, 17 I N.Y. 384, 390, 64 N.E. 163, 164 (1902).

Trade symbol infringement is the use of a commercial identification by one businessman that purchasers are likely to confuse with the commercial identification previously used by another. R. Dole, Territorial Trademark Rights and the antitrust Laws 4-II (Michigan Legal Publications 1965). For example, in Standard Oil Co. of New York v. Standard Oil Co. of Maine, 38 F.2d 677 (D. Me.), modified on other grounds, 45 F.2d 309 (Ist Cir. 1930), the longestablished Standard Oil Company of New York was held entitled to enjoin the use of the "Standard Oil Company" by a newly-organized corporation that was engaged in the distribution of petroleum products in northern New England.

${ }^{25}$ UNIFORM ACT $\S 2$ (b) provides: "In order to prevail in an action under this act, a complainant need not prove competition between the parties or actual confusion or misunderstanding."

${ }^{26} I d$. $\S 3($ a) states: "A person likely to be damaged by a deceptive trade practice of another 
declarations that neither competition between the parties, actual confusion or misunderstanding, intent to deceive, nor provable monetary damage need be established to obtain relief. These sections do not preclude use of such factors as evidence of probable damage, but make clear that other evidence will also suffice. A wholesaler with an exclusive sales agency for a trademarked beverage, for example, may be damaged by repeated false assertions that the beverage is mislabeled, even though the retailer who makes the claims is honestly mistaken about their truth. ${ }^{27}$ In addition to authorizing injunctive relief against deceptive trade practices, ${ }^{28}$ the Uniform Act preserves other state remedies that are not expressly superceded by the Uniform Act $^{29}$ and gives discretion to the court to award attorneys' fees to the prevailing party if a complainant has brought an action known to be groundless or if a defendant has deliberately engaged in a deceptive trade practice. ${ }^{30}$

\section{Consumer Standing Under the Uniform Deceptive Trade Practices ACT}

The Uniform Deceptive Trade Practices Act confers standing on any "person likely to be damaged by a deceptive trade practice of another . . . ." "Person" is defined as "an individual, corporation, government, or governmental subdivision or agency, business trust, estate, trust, partnership, unincorporated association, two or more of

may be granted an injunction against it under the principles of equity and on terms that the court considers reasonable. Proof of monetary damage, loss of profits or intent to deceive is not required...."

"Cf. Joseph E. Seagram and Sons v. Restaurant Cherry Lane, Inc., 118 U.S.P.Q. 41 (N.Y. Sup. Ct. 1958).

io UNIFORM ACT $\$ 3$ (a). See notc 26 supra. For discussion of the reasons for omitting a damage remedy from the Uniform Act, see Dole, supra note 22, 51 MiNN. L. REV. at 1017-18.

29 UNIFORM ACT \& 3(c). Section 2(c) coordinately provides: "This section does not affect unfair trade practices otherwise actionable at common law or under other statutes of this state."

${ }^{20} I d$. $\S 3(\mathrm{~b})$. With a caveat that attorneys' fees could be assessed against a defendant only if the court found that he had willfully engaged in a deceptive trade practice, the original version of the Uniform Act authorized a court to award attorneys' fees to the prevailing party "in exceptional cases." 9A UNIFORM LAws ANN. (Supp. 1967, at 17). In states where the original Uniform Act has been enacted, the "uniform interpretation" clause in $\S 5$ should lead judges to interpret original $\S 3(\mathrm{~b})$ in light of the 1966 amendment until conforming amendments are made. For cxample, a strikc suit under the Uniform Act would constitute an "exceptional circumstance" justifying the award of attorneys' fees to the defendant under the original wording of $\S 3(\mathrm{~b})$. The 1966 amendment, of course, expressly singles out this situation as an instancc in which attorneys' fees can be recovered.

${ }^{31}$ UNIFORM ACT $\S 3(\mathrm{a})$. 
any of the foregoing having a joint or common interest or any other legal or commercial entity." 32 On first reading, there would seem to be little doubt that a consumer would qualify as "a person likely to be damaged." However, there are several possible objections to this interpretation: (1) The Uniform Act originated as an effort to reform the law of business torts, not consumer torts; ${ }^{33}$ (2) the limitation of relief under the Uniform Act to an injunction can be considered to be more compatible with business than with consumer interests since an individual businessman is more apt to be damaged on a continuing basis by sustained deceptive trade practices than an individual consumer; ${ }^{34}$ and (3) it is at least superficially difficult to comprehend how consumers could effectively utilize the Uniform Act. A consumer who has discovered a deceptive trade practice should not need an injunction to protect himself from the deceptive trade practice in the future, and a consumer who has not discovered a deceptive trade practice cannot be aware that the Uniform Act has been violated. ${ }^{35}$

None of these possible objections to consumer standing outweighs the plain words of the statute which confer standing on any "person likely to be damaged." It is the likelihood of future damage from a deceptive trade practice which is the essential element of standing, not the economic level at which a plaintiff functions. Although the Commissioners on Uniform State Laws initiated the study which led to the promulgation of the Deceptive Trade Practices Act at the request of the American Bar Association Section of Patent; Trademark, and Copyright Law, a business-oriented group, ${ }^{36}$ the Commissioners almost immediately perceived the utility of allowing both business and consumer suits against deceptive trade practices.

In 1962 the Special Committee charged with formulation of the Uniform Act presented two alternative substantive provisions for consideration by the National Conference sitting as a Committee of

\footnotetext{
"Id. §I(5).

"Starrs, supra note 16 , at 106.

"Id.

3s Dole, supra note 22, 76 Y ALE L.J. at 500. A typical example would be the apparent offering of prestige items at bargain prices by a competitor who is in reality engaging in flagrant deceptive advertising. Cf. American Washboard Co. v. Saginaw Mfg. Co., 103 F. 281 (6th Cir. 1900). 67.

3 A Ba Patent, Trademark, and Copyright Law Section 45 (1958); 1959 Handbook 66-
} 
the Whole. Following an extended discussion in which various opinions concerning consumer standing were aired ${ }^{37}$ the Committee of the Whole declined to express a preference on the issue of consumer standing and left the matter in the hands of the Special Committee. ${ }^{38}$ Shortly after this decision was reached, Commissioner Wade of Tennessee, a member of the Special Committee which drafted the act, pinpointed the language of the draft which gave a consumer standing. Line 4 of section 2 of the $1962 \mathrm{draft}$ authorized relief "upon the suit of one damaged or likely to be damaged thereby . . . ." ${ }^{39}$ Commissioner Wade stated: "As to line 4, it would very definitely, 1 think, indicate that the consumer does have a cause of action, so that when the decision is made on that, some reference should be made to line 4 in this connection." ${ }^{4 c}$

Commissioner Wade's comments were the last significant reference to the consumer standing issue on the floor of the National Conference during the formulation of the Uniform Act. Thus, the similarity of the test for standing in the promulgated act to the test for standing in the 1962 draft makes clear that the promulgated act carries forward the grant of consumer standing which Commissioner Wade perceived in the 1962 draft. ${ }^{41}$ The 1962 Proceedings in the Committee of the Whole also make clear that the Committee of the Whole left this issue to be resolved by the Special Committee. No serious challenges were subsequently raised to the manner in which the issue was resolved. ${ }^{42}$ Although the proceedings of the National Conference of Commissioners on Uniform State Laws are not

${ }^{37}$ Proceedings in Committee of the Whole of the National Conference of Commissioners on Uniform State Laws, August 4, 1962 at 11-35 [hereinafter cited as 1962 Proceedings]. Early in the discussion Commissioner G.M. Fuller of Oklahoma, the Chairman of the Spccial Committee in charge of the act, was asked the following question: "Mr. Kohn: The next question is: Is it intended that a consumer be allowed to sue as well as a competitor? Mr. Fuller: Yes. It is possible that that could occur, and it is intended to be for the protection of both the businessman and the consumer." Id. at 10.

${ }^{38}$ Id. at $35-44$.

${ }^{39}$ Id. at 45.

${ }^{40}$ Id. at 47.

"The absence in the promulgated act of language conferring standing on a person "damaged" merely refleets the decision to omit a damage remedy from the final version of the act. A pcrson who has been damaged does not require injunctive relief unless he is also likely to continue to be damaged. Proceedings in Committeee of the Whole of the National Confcrence of Commissioners on Uniform State Laws, August. 4, 1964 at 102-03 [hereinafter cited as 1964 Proceedings].

${ }^{2}$ At one point the author questioned whether consumers could satisfy the "likelihood of damage" test for standing, but he was flatly rebuffed by Commissioner Jestrab and the issue was dropped. 1964 Proceedings at 14-19. 
conclusive respecting the meaning to be given individual state enactments, the proceedings suggest highly persuasive interpretations of language that has been adopted in the same form proposed by the National Conference. The proceedings thus furnish strong support for allowing consumer suits under the Uniform Act.

The Official Prefatory Note to the Uniform Act provides additional confirmation of consumer standing. California Civil Code section $3369^{43}$ is described as "a rough prototype" of the Uniform Act, ${ }^{+4}$ and adjudications under section 3369 are said to reflect principles crystallized in the uniform statute. ${ }^{45}$ One of the California cases cited in the Official Prefatory Note, People v. National Research Co. ${ }^{46}$ determined that the essential test of unfair or fraudulent business practice under section 3369 was a likelihood of public deception. In reaching this conclusion the California court rejected the argument that the public deception must occur in the course of business competition, reasoning that the broad language of the statute indicated a legislative intent to be inclusive rather than restrictive concerning the practices to be enjoined. ${ }^{47}$ National Research was a section 3369 suit by the California Attorney General against an organization which sold bogus governmental forms to persons seeking to locate delinquent debtors. ${ }^{48}$ Nonetheless, its inclusive

43 The California statute provides in part: "2. Any person performing or proposing to perform an act of unfair competition within this State may be enjoined in any court of competent jurisdiction. 3. As used in tbis section, unfair competition shall mean and include unlawful, unfair or fraudulent business practices and unfair, untrue or misleading advertising and any act denounced by Business and Professions Sections 17500-17535, inclusive." CAL. CIv. CodE $\S 3369$ (West Supp. 1967).

4 1966 HaNDBOoK at 300.

4" "[T] Athens Lodge No. 70 v. Wilson, 117 Cal. App. 2d 322, 255 P.2d 482 (1953); what constitutes an unfair or fraudulent business practice under its terms is a question of fact with the essential test being likelihood of public deception, People v. National Research Co., 201 Cal. App. 2d 765, 20 Cal. Rptr. 516 (1962)." 1966 HANDBOOK at 301.

to 201 Cal. App. 2d 765, 20 Cal. Rptr. 516 (1962).

"We conclude that the equitable relief authorized by Civil Code, section 3369, is not circumscribed by any prerequisite showing that the conduct in question be limited to the field of business competition.

"The very breadth of the terms used by the Legislature indicate, in our judgment, an intent to be inclusive rather than restrictive in the practices to be enjoined. We refrain from construing the language narrowly in a field where the trend is opposed to unfair trade practices which affect the public interest." People v. National Research Co., 201 Cal. App. 2d 765, 771, 20 Cal. Rptr. 516, 520 (1962).

${ }_{45}$ Unlike the Uniform Act, $\S 3369$ expressly grants standing to the state attorney general. Compare UNIFORM ACT $\S 3($ a) with CAL. CIV. CODE $\S 3369$ (5) (West 1964). 
construction of the scope of section 3369 supports interpretation of the Uniform Act to encompass consumer as well as business torts. ${ }^{49}$

This interpretation is further supported by the purpose of the Uniform Act as stated in the Official Prefatory Note: to remove common law restrictions and provide a private injunctive remedy to those persons likely to be damaged by deceptive trade practices. ${ }^{50}$ Thus, the objectives of the Act are phrased in the broadest possible terms; and the language concerning standing, which Commissioner Wade believes is sufficient to create consumer standing, is stressed. This is a natural consequence of Commissioner Fuller's observation during the 1962 Committee of the Whole proceedings that consumers are as likely to be damaged by deceptive trade practices as businessmen. ${ }^{51}$

The Uniform Act's provision for equitable relief is not inconsistent with consumer standing to sue. Equitable retief against deceptive trade practices can be of benefit to all consumers who desire to maintain a commercial relationship with a merchant who has demonstrated a penchant for deceptive trade practices. A court order to refrain from specific deceptive conduct with respect to consumers or face penalties for contempt of court is a persuasive inducement to cease misfeading one's clientele. ${ }^{52}$

\footnotetext{
*9 Section 3369 expressly confers standing on "any person aeting for the interest of itself, its members or the general public." CAL. CIV. CODE $\S 3369(5)$ (West 1964). By dispensing with injury as a prerequisite for standing, $\S 3369$ thus allows "private attorneys general" to enjoin deceptive trade practices. Dole, supra note 22, 76 YALE L.J. at 498-99. On the other hand, the Uniform Act does not eliminate reference to potential damages in determining the issue of standing. UNIFORM ACT $\S 3($ a).

This distinction between $\S 3369$ and the Uniform Act by no means precludes consumer standing under the latter. The distinction simply means that a consumer must establish a likelihood of damage from a deceptive trade practice before he can sue under the Uniform Act.

${ }^{30} 1966$ HANDBooK at 299. The Prefatory Note further states:

"The Uniform Act is designed to bring state law up to date by removing unduc restrictions on the common law action for deceptive trade practices. Certain objectionable practices are singled out, but the courts are left free to fix the proper ambit of the act in case by case adjudication.

"The Uniform Act provides a private conjunctive [sic] remedy to persons likely to suffer pecuniary harm for [sic] conduct involving cither misleading identification of business or goods or false or deceptive advertising."

s1 1962 Proceedings at 26-27. (Commissioner Fuller also noted that consumers would be less likely to suc than businessmen). In point of fact, consumers are in all probability even more likely to be damaged than businessmen. Consumers may not be able to identify deceptive techniques as readily as businessmen and cannot, as businessmen can, minimize their injury by a parallel adoption of deceptive practices. See Comment, Translating Sympathy for Deceived Consumers into Effective Programis for Protection, 114 U. PA. L. REv. $395-97$ (1966).

$\therefore$ In addition to criminal penalties, violation of an injunction can result in civil liability to consumers damaged by the violation. Starrs, supra note 16 , at $90-91$.
} 
From a consumer standpoint, the principal defect of the injunctive remedy of the Uniform Act is not its usefulness but its expense. The Uniform Act does not authorize the recovery of damages from which the cost of litigation can be recouped. However, the attorneys' fees provision of the Uniform Act compensates for this. The act permits the award of attorneys' fees to a successful plaintiff where the defendant is found to have willfully engaged in a deceptive trade practice,$^{53}$ and, as in civil rights litigation, the courts should take due note of the social value of proceedings under the Uniform Act in making such awards. In Newman v. Piggie Park Enterprises, Inc. ${ }^{54}$ a recent class action to enjoin racial discrimination in public accommodations, the successful plaintiffs sought to recover a reasonable attorney's fee under the Civil Rights Act of 1964, which permits such awards to the prevailing party in the court's discretion..$^{55}$ The Fourth Circuit Court of Appeals held that an attorney's fee should only be recoverable where the defendant had introduced bad faith defenses for the purpose of delay. ${ }^{56}$ The Supreme Court, however, modified the decision per curiam, reasoning that when a plaintiff brings an action for injunctive relief under the Civil Rights Act of 1964, he aids not only himself, but all other persons subject to the same discrimination. The Court concluded that without recovery of attorney's fees, few aggrieved persons would be able to maintain such actions, and the policies which Congress sought to effectuate through the Civil Rights Act would be deprived of the private injunction as a viable means of enforcement. ${ }^{57}$

The Newman case suggests an additional reason to believe that consumers will take advantage of the opportunity to obtain an injunction that is provided by the Uniform Act. The NAACP Legal Defense and Educational Fund, Inc., appeared for the plaintiffs in Newman, and this organization, and others like it, are evincing an increasing interest in financing consumer litigation. ${ }^{58}$

\footnotetext{
"UNIFORM ACT \& 3(b).

s4 377 F.2d 433 (4th Cir. 1967), modified, 390 U.S. 400 (1968) (per curiam).

$" 42$ U.S.C. $\$ 2000 \mathrm{a}-3$ (b) (1964).

\$6 377 F.2d at 433 .

"390 U.S. at 402. See generally Ehrenzweig, Reimbursement of Counsel Fees and the Great Society, 54 CALIF. L. Rev. 792 (1966).

ss See Schrag, Ghetto Merchants-A Study in Deception, 159 New Republic 17 (1968) (article by a consumer test case counsel for the NAACP Legal Defcnse and Educational Fund, Inc.). In Russell v. Coburn Corp., No. 6338/68 (N.Y. Sup. Ct., Bronx Cty. 1968), a consumer class action brought under the New York Personal Property Law, the NAACP Legal Defense and Education Fund has offered either to accept an award of attorneys' fees which would be
} 
Office of Economic Opportunity Neighborhood Legal Services Attorneys can also utilize the Uniform Act. Although Neighborhood Legal Services Attorneys can only represent indigent clients and must refer "fee-generating" cases to private attorneys, ${ }^{59}$ private attorneys may not regularly accept referrals of Uniform Act cases. A court has full discretion to deny the recovery of fees in situations in which the Uniform Act permits their award ${ }^{66}$ a circumstance which may lessen private attorneys' interest in such referrals. As long as a potential plaintiff is indigent and no private attorney cares to gamble on the court's exercise of its discretion, Legal Services Attorneys can take cases arising under the Uniform Act. ${ }^{61}$

Resolution of the problem of litigation expense removes only one obstacle to consumer actions under the Uniform Act. Another problem, perhaps the most serious objection to consumer standing, is the difficulty of relating consumer suits to the "likely to be damaged" test of section 3(a) ${ }^{62}$ Only a person "likely to be damaged" can sue for injunctive relief under the act; yet why should a consumer who knows that a merchant is engaging in trickery need an injunction to protect himself in the future? On the other hand, how can consumers who are likely to be damaged in the future because they do not know about the trickery ever realize that they have standing to sue? Indeed, will not their discovery of the trickery, which will alert them to the possibility of suit under the Uniform Act, ipso facto destroy their standing by removing any likelihood of future injury ? $^{63}$

As long as a consumer desires to have a continued relationship

used to finance future consumer litigation or to waive attorneys' fees altogether. Plaintiff's Memorandum of Law in Opposition to a Motion to Dismiss the Complaint, Russell v. Coburn Corp., supra, at 60-62. Volunteer attorneys provide another source of counsel. Shamberg, The Utilization of Volunteer Attorneys to Provide Effective Legal Services for the Poor, $63 \mathrm{Nw}$. U.L. Rev. 159 (1968). Nevertheless, the need is great and the cost of representation high. Schrag, supra, calls for legislation which would permit consumers to recover reasonable attorneys' fees from deeeptive-practice-prone merchants.

s9 Johnson, An Analysis of the OEO Legal Services Program, 38 Miss. L.J. 419, 426 (1967).

${ }^{\circ}$ UNIFORM ACT § 3(b); Dole, supra note 22, 76 YALE L.J. at 495.

${ }^{61}$ See Office of Economic Opportunity, Legal Services Guidelines 20-21; Note, Neighborhood Law Offices: The New Wave in Legal Services for the Poor, 80 HARV. L. REv. 805, 846-47 (1967).

${ }^{62}$ UNIFORM ACT $\S 3(\mathrm{a})$.

${ }^{63}$ These questions were discussed briefly during the 1964 Proceedings of the Committec of the Whole. The author and Commissioner Jestrab engaged in a colloquy which ended as follows: "Mr. Dole: I am suggesting to you . . . that a customer . . . would have no standing to sue under this Act onee he were aware of the deception. Mr. Jestrab: 1 don't think that's right. 1 don't think that's true at all." 1964 Proceedings at 19. Commissioner Jestrab apparently had the 1962 proceedings more clearly in mind than the author at this juncture. 
with a merchant whom he has observed in a deceptive trade practice which is not transparent once discovered, there can be a likelihood that the consumer will be damaged by repetition of similar deceptive trade practices. It is no answer to say that the consumer can protect himself by dealing with someone else. Many consumers rely heavily on neighborhood merchants and there may not be satisfactory alternative sources of supply in the neighborhood. ${ }^{64}$ However, even where alternative sources of supply are available, a consumer who chooses to deal with a perceived deceptor can still qualify for relief as long as repetition of the deception will be difficult to detect and there is a probability that the deception will be repeated. Thus, a consumer who wishes to deal with a merchant who has been known to engage in such opaque deceptive trade practices as price misrepresentation, substitution of different goods from those ordered, or bait advertising, ${ }^{65}$ each of which is specifically proscribed by the Uniform Act, ${ }^{66}$ can enjoin future violations of the Uniform Act where the nature of the past violations raises a probability of additional violations. A consumer's interest in dealing with the merchant of his choice is entitled to greater weight than a merchant's desire to avoid equitable relief against deceptive trade practices.

Of course, a merchant is also privileged to select the persons with whom he chooses to deal. ${ }^{67} \mathrm{~A}$ merchant, however, cannot necessarily moot a suit under the Uniform Act by ceasing to do business with the consumer seeking injunctive relief. Where the cessation of business is intended primarily to deprive the consumer-plaintiff of standing, a court can either disregard the cessation of business or utilize its equity powers to preserve its jurisdiction at least until the pending litigation has been adjudicated. ${ }^{68}$ Indeed, it can be plausibly maintained that

\footnotetext{
64 This is especially true of the urban poor. See D. Caplovitz, The Poor PAy More, chs. 4 \& 5 (1967).

${ }^{65}$ These types of deception are common in urban areas. Id. at 142-53. Bait advertising is the advertising of a bargain which one does not intend to sell in order to attract customers who can be switched to a higher-priced, unadvertised item. Id. at 142-44.

os "A person engages in a deceptive trade practice when, in the course of his business, vocation, or occupation, he: (1) passes off goods or services as those of another; . . . (9) advcrtises goods or services with intent not to sell them as advertised; (10) advertises goods or services with intent not to supply reasonably expectable public demand, unless the advertisement discloses a limitation of quantity; (11) makes false or misleading statements of fact concerning the reasons for, existence of, or amounts of price reductions." UNIFORM ACT $\S \S 2(a)(1),(9),(10), \&(11)$.

${ }^{67}$ Cf. United States v. Colgate \& Co., 250 U.S. 300 (1919).

${ }^{68}$ Cf. Bergan Drug Co. v. Parke, Davis \& Co., 307 F.2d 725 (3d Cir. 1962); Flynn, A Surve." of Injunctive Relief Under State and Federal Antitrust Laws, 1967 UTAH L. Rev. 344, 375.
} 
such a calculated refusal to deal would be a violation of section 2(a)(12) of the Uniform Act which would warrant both an injunction and an award of attorneys' fees to the consumer-plaintiff. Section 2(a)(12) forbids "conduct which similarly creates a likelihood of confusion or of misunderstanding," ${ }^{\circ 9}$ and a refusal to deal that was designed to preclude injunctive relief against specific violations of the Uniform Act would seem to be conduct falling within its terms. On the other hand, where a merchant has reasons for breaking relations with a consumer-plaintiff that are unrelated to the pending law suitfor example, the consumer's failure to make stipulated monthly payments-the merchant's refusal to continue to deal with the consumer-plaintiff will ordinarily moot a suit under the Uniform Act by legitimately removing any likelihood of future damage to the individual consumer-plaintiff. Nevertheless, in the case of a consumer class action, this will merely require a reshuffling of class representatives and will not moot the proceeding with respect to those members of the class with whom the merchant continues to deal.

The standing of individual consumers to sue is the predicate of consumer class actions under the Uniform Act. There appears to be no reason why a group of individual consumers with standing cannot utilize the efficient class action device as a surrogate for individual actions. Indeed, the Uniform Act invites the use of class actions by defining "person" to include "an individual, corporation, government or governmental subdivision or agency, business trust, estate, trust, partnership, unincorporated association, two or more of any of the foregoing having a joint or common interest, or any other legal or commercial entity." ${ }^{70}$ A group with a joint or common interest is, of course, precisely the kind of group which can bring a class action"1 so that the definition of "person" implies that class actions are permissible under the Uniform Act. This view is also buttressed by the purpose of the act. The maintenance of class actions will facilitate the goal of providing a private injunctive remedy to all persons likely to suffer pecuniary harm from deceptive trade practices. ${ }^{72}$

A consumer class action involves a number of procedural niceties.

\footnotetext{
${ }^{69}$ UNIFORM ACT $\S 2(a)(12)$. The Official Comment to $\S 2(a)(12)$ states that the subsection "permits the courts to block out new kinds of deceptive trade practices." 1966 HaNDBOok at 310. However, this does not preclude application of the subsection to conduct which results in perpetuation of recognized deceptive trade practices.

${ }^{30}$ UNIFORM ACT \& I(5) (emphasis added).

"E.g., Fed. R. Civ. P. 23(a) \& (b); Z. Chafee, Some Problems of Equity 213-24 (1950).

321966 HaNDBOoK at 299; $c f$. Oatis v. Crown Zellerbach Corp., 398 F.2d 496 (5tb Cir. 1968).
} 
However, before considering the mechanics of class actions, it should be pointed out that even the existence of individual consumer standing to sue raises joinder problems under the Uniform Act. It will be recalled that the deceptive trade practices singled out by the act can be subdivided into trade symbol infringement, ${ }^{73}$ false disparagement, ${ }^{74}$ and deceptive advertising. ${ }^{75}$ These deceptive trade practices vary in their impact on consumers and businessmen. Trade symbols are extremely valuable property, ${ }^{76}$ and a trade symbol user can be seriously injured by any concurrent rights to his trade symbol acquired by other businessmen. ${ }^{77}$ For those reasons, joinder of the lawful user of the trade symbol in question should be considered indispensable in any consumer suit under the Uniform Act which involves trade symbol infringement. The interests of the lawful trade symbol user cannot ordinarily be adequately protectcd in any other way and consumer interests will generally be advanced by the lawful trade symbol user with or without a consumer suit. ${ }^{78}$ The volume of business-initiated litigation involving trade symbol infringement is immense. ${ }^{79}$

False disparagement also involves significant interests of a third party, the business which is the target of the disparagement. This business has an understandable concern in having the truth or falsity of the charges against it properly litigated. The target business also is often in the best position to supply information concerning the truth

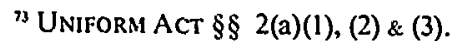

"Id, at $\S 2(\mathrm{a})(8)$.

"Id. at $\S \S 2(\mathrm{a})(4),(5),(6),(7),(9),(10) \&(11)$.

${ }^{76}$ In 1963, for example, Polaroid Corporation adduced evidence that it had sold over 450 million dollars worth of "Polaroid" products and had spent approximately 30 million dollars in advertising products identified by the trade symbol. Polaroid Corp. v. Polaraid, Inc., 319 F.2d 830, 832 (7th Cir. 1963).

"See United Drug Co. v. Theodore Rectanus Co., 248 U.S. 90 (1918); Hanover Star Milling Co. v. Metcalf, 240 U.S. 403 (1916); R. Dole, Territorial Trademark Rights and the ANtitrust Laws 24-30 (Michigan Legal Publications 1965).

${ }^{7}$ Sce Fed. R. Civ. P. 19; F. James, Civil. Procedure 413 (1965). New Rule 19 requires a court to weigh the following factors in deciding if a party's presence is indispensible to a lawsuit: whether a judgment rendered in the party's absence might be prejudicial to him; whether prejudice can be avoided by protective provisions; whether a judgment rendered in the person's absence will be adequate; and whether the plaintiff will have an adequate remedy if the action is dismissed for non-joinder. FED. R. Civ. P. 19(b). Professor James indicates that similar facttors were weighed under the former federal rule and in various states. F. JAMES, supra at 41428.

"See Derenberg, The Twentieth Year of Administration of the Lanham Trademark Act of 1946, 57 TRADEmaRK ReP. 643 (1967); Derenberg, The Nineteenth Year of Adninistration of the Lanham Trademark Act of 1946, 56 TRADEMARK REP. 691 (1966).
} 
or falsity of the statements. On the other hand, a consumer-plaintiff may well have sources of information and representation adequate to protect the target business' interests. These considerations suggest that the target of false disparagement should ordinarily be made a party to a consumer suit where joinder is possible but that the suit should be allowed to proceed where joinder cannot be achieved. ${ }^{8 \mathrm{C}}$

Deceptive advertising differs from trade symbol infringement and false disparagement in that deceptive advertising generally has greater adverse impact on consumers than on any specific business. Consumers may or may not be injured by trade symbol infringement or false disparagement. Neither of these torts necessarily involves misrepresentation of what is being offered for sale by the tortfeasor. ln contrast, the essence of deceptive advertising is the misrepresentation of what is offered for sale. ${ }^{81} 1 \mathrm{t}$ is also difficult to pinpoint particular businessmen who are uniquely injured by deceptive advertising. All of a deceptive advertiser's competitors and their suppliers are usually affected. Thus, a consumer suit against deceptive advertising typically poses no additional joinder problems because consumers have a definable and distinct interest in the suppression of deceptive advertising which is unlikely to trench deeply upon the interests of any particular legitimate business.

\section{Procedural Nuances of Consumer Class actions}

State class action procedure is regulated by various court rules and statutes.$^{82}$ Because an increasing number of states have opted to follow a federal model, some of the procedural aspects of consumer class actions will be analyzed in terms of both the new Federal Rule 23, which became effective in $1966,{ }^{83}$ and the former Rule 23 which was implemented in $1938 .{ }^{84}$ The principal difference between them re-

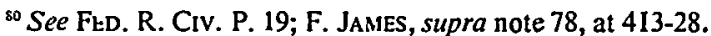

st E.g., People v. Abbott Maintenance Corp., 11 App. Div. 2d I36, 20I N.Y.S.2d 895 (1960) (per curiam), affd mem., 9 N.Y.2d 810, 175 N.E.2d 341, 215 N.Y.S.2d 761 (1961). Sce note 24 supra.

${ }^{32}$ Starrs, The Consumer Class Action: Considerations of Equity and Procedure in National Institute for Education in LaW and Poverty, Handbook on Consumer Law $116-17$ (2d ed. 1968).

${ }^{53} 39$ F.R.D. 69, 95-107 (1966).

S4 FED. R. CIV. P. 86(a). Former Rule 23 has been adopted in numerous states. 3A J. Moore, Fiederal Practice ff 23.03 at 3417 n. 7 (2d ed. 1968); see, e.g., Braasch v. Goldschmidt, 4 I Del. Ch. 519, 199 A.2d 760 (1964). New Rule 23 has already been adopted in Arizona and Minnesota and proposed for adoption in New Jersey. ARIz. Rev. Stat. ANN. Rule 23 (Supp. 1967); Minn. Stat. AnN. District Ct. Rule 23 (Supp. 1968); Conover v. Packanack Lake
} 
lates to the contemplated scope of the judgment in a class action. Under new Rule 23 the judgment, whether or not favorable to the class, ordinarily extends to all the members of the class..$^{85}$ Under former Rule 23 the judgment in some class actions only extended to members of the class who had become parties to the action through joinder or intervention. ${ }^{86}$ This distinction between new and former Rule 23 is essentially a difference in the probable res judicata effect of a judgment on the members of a class. Although new Rule 23 does not alter the established principle that the court which adjudicates an action cannot simultaneously determine the res judicata effect of its own judgment, ${ }^{87}$ the broader terms of the judgments authorized by new Rule 23 should induce a corresponding expansion in res judicata effect. $^{\text {ss }}$

\section{New Rule 23}

New Rule 23(a) establishes four general prerequisites to the maintenance of a class action. It must appear (1) that the class is so numerous that joinder of all members is impracticable; (2) that there are questions of law or fact common to the class; (3) that the claims or defenses of the class representatives are typical of the claims or defenses of the class; and (4) that the class representatives will fairly and adequately protect the interests of the class. ${ }^{89}$

Aside from specifying the general criterion that a group must be too large to be practicably joined, new Rule 23 does not indicate how large a group must be in order to justify class action treatment. ${ }^{96}$ Accordingly, the federal courts have exercised wide discretion in deciding whether a proposed class is of sufficient size.91 A group of forty has been considered sufficient under former Rule $23 .^{92}$ It has also

Country Club \& Community Ass'n., 94 N.J. Super. 275, 279 n.l, 228 A.2d 78, 80 n.i (App. Div. 1967). Furthermore, federal courts' interpretations of the Federal Rules of Civil Procedure have been known to influence state courts in the application of state rules which were not derived from federal models. E.g., Verdin v. Thomas, 191 So. 2d 646, 650-51 (La. Apps. 1966).

"See generally Kaplan, Continuing Work of the Civil Committee: 1966 Amendments of the Federal Rules of Civil Procedure (I), 81 HaRv. L. Rev. 356, 390-93 (1968). Persons who opt out of a (b)(3) class action are excepted. See notes 125-27 infra and accompanying text.

${ }^{86}$ Kaplan, supra note 85 , at $376-86$.

"39 F.R.D. 69, 106 (1966) (Advisory Committee's Note to new Rule 23(c)(3)).

" 2 W. Barron \& A. Holtzoff, Federal Practice and Procedure $\$ 572$ (C. Wright Rev. Ed. Supp. 1967).

${ }^{59}$ FED. R. CIV. P. 23(a)(1)-(4).

${ }^{50}$ Id. 23(a)(1).

"1 Demarco v. Edens, 390 F.2d 936, 845 (2d Cir. 1968); Cypress v. Newport News Gen. \& Nonseetarian Hosp. Ass'n, 375 F.2d 648, 653 (4th Cir. 1967).

${ }^{22}$ Citizens' Banking Co. v. Monticello State Bank, 143 F.2d 26I, 264 (8th Cir. 1944). 
been held that, as long as the group involved is well-defined and obviously substantial, a plaintiff does not have to specify the precise number of persons in the group in order to bring a class action."? There are frequently enough consumers affected by the same deceptive trade practice to permit class action treatment. This is true, for example, where a deceptive advertisement is disseminated by means of mass media, ${ }^{, 4}$ and where substantially similar deceptive statements are repetitively used in door-to-door or in-store selling."5

Not only the size and composition of the class, but also the nature of the claim presented by that class must be scrutinized under Rule 23 . There is an obvious relationship between the requirement that there be questions of law or fact common to the class $^{96}$ and the requirement that the claims of the class representatives must be typical of the class. ${ }^{97}$ These requirements mean that substantially the same deception must have been practiced on the entire group of consumers that are asserted to constitute a class, including the class representatives..$^{98}$ The requirement that the class representatives have claims that are typical of the class ${ }^{99}$ is also related to the requirement that they must fairly and adequately represent the class. ${ }^{160}$ The justification seems to be that a person will fight harder for that which affects him directly. ${ }^{161}$ Again, a substantial similarity in the nature of

${ }_{93}$ Jacobs v. Paul Hardeman, Inc., 42 F.R.D. 595, 598 (S.D.N.Y. 1967); Fischer v. Kletz, 41 F.R.D. 377, 383-84 (S.D.N.Y. 1966).

${ }^{9}$ See, e.g., People v. Glubo, 5 N.Y.2d 461, 158 N.E.2d 699, 186 N.Y.S.2d 26 (1959) (case shows the large number of consumers who can be affected by fraudulent advertising and sales practices).

${ }^{95}$ E.g., People v. Abbott Maintenance Corp., 11 App. Div. 2d 136, 201 N.Y.S.2d 895 (1960) (per curiam), aff d mem., 9 N.Y.2d 810, 175 N.E.2d 341, 215 N.Y.S.2d 761 (1961) (in-store selling); Lefkowitz v. 1TM, Inc., 52 Misc. 2d 39, 275 N.Y.S.2d 303 (Sup. Ct. 1966) (door-todoor selling).

${ }^{26}$ FED. R. CIV. P. 23(a)(2).

${ }^{97}$ Id. 23(a)(3).

${ }^{98}$ Cf. Brennan v. Midwestern United Life Ins. Co., 259 F. Supp. 673, 683 (N.D. III. 1966); Kronenberg v. Hotel Governor Clinton, Inc., 41 F.R.D. 42 (S.D.N.Y. 1966). A leading New York case details a standardized bait advertising scheme which was honed to perfection by a series of instruction sessions or clinics for the bait advertiser's salesmen. People v. Glubo, 5 N.Y.2d 461, 158 N.E.2d 699, 186 N.Y.S.2d 26 (1959); accord, Robnet v. Miller, 105 Ohio App. 536, I52 N.E.2d 763 (1957). Bait advertising, of course, occurs where a seller seeks to attract customers by advertising at a low price an item that he does not intend to sell in more than nominal amounts. The seller then uses various artifices in order to switch persons who respond to his advertisements to unadvertised, higher-priced merchandise. See Note, State Control of Bait Advertising, 69 Y ALE L.J. 830, 832 (1960).

${ }^{29}$ FED. R. CIV. P. 23(a)(3).

${ }^{100}$ Id. 23(a)(4).

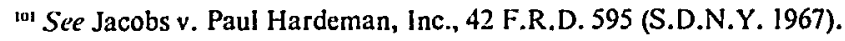


the deception practiced on a group of consumers will help to satisfy this requirement. ${ }^{102}$

The Second Circuit in Eisen v. Carlisle \& Jacquelin ${ }^{103}$ recently declared that the notion of adequate representation also required the class representatives to provide counsel "qualified, experienced and generally able to conduct the proposed litigation." ${ }^{10+}$ Concerned with the prospect of a collusive suit, the court further demanded assurance that the interests of the class representatives were not adverse to those of the other members of the class. On the other hand, the Second Circuit dismissed consideration of quantitative representation, the number of persons appearing as class representatives in comparison with the total number in the class, as a determinant of the adequacy of representation. The court stated: "If we have to rely on one litigant to assert the rights of a large class then rely we must." 165

The Eisen concept of adequate representation is a landmark interpretation of new Rule $23^{1166}$ which greatly facilitates consumer class actions. Quantitative representation, considered important under the former rule, ${ }^{167}$ presents a substantial obstacle to consumer class actions where the individual stakes are small. $\ln$ this situation, the consumer class may be fortunate to find a single representative who will fight for principle. ${ }^{\text {Ics }}$

After satisfying the general prerequisites discussed above, a class action must meet at least one of several additional requirements specified in section b of new Rule 23. New Rule 23(b)(l) authorizes a class action where individual litigation between members of a class and its opponent could result in the establishment of incompatible standards of conduct for the opponent, ${ }^{169}$ and where adjudications with respect to individual members of a class would, as a practical matter, be dispositive of the interests of the other members of the class. ${ }^{110}$

\footnotetext{
${ }^{102}$ See authorities cited in note 98 supra.

103 391 F.2d 555 (2d Cir. 1968).

${ }^{100} I d$. at 562 .

${ }^{1005}$ Id. at 563 .

10s The Eisen view has already been followed. Hohmann v. Packard instrument Co., 399 F.2d 711 (7th Cir. 1968); Minnesota v. United States Steel Corp., 44 F.R.D. 559 (D. Minn. 1968).

iv' E.g., Pelelas v. Caterpillar Tractor Co., 113 F.2d 629 (7th Cir.), cert. denied, 311 U.S. 700 (1950).

${ }^{108}$ See Daar v. Yellow Cab Co., 67 Cal. 2d 695, 433 P.2d 732, 63 Cal. Rptr. 724 (1967) (1n Bank).

${ }^{169}$ Fed. R. Civ. P. 23(b)(I)(A).

${ }^{10} I d .23(\mathrm{~b})(\mathrm{I})(\mathrm{B})$.
} 
There are several reasons why it is highly unlikely that individual consumer suits under the Uniform Act would establish incompatible standards for a merchant's conduct. In the first place, although the details of successive injunctions against deceptive trade practices could differ, there would be a natural tendency for later decrees to be influenced by the terms of the first decree."' Moreover, once one consumer has succeeded in enjoining particular conduct, a merchant may well have to revise his marketing methods with respect to all of his clientele. This eventuality would make it improbable that duplicative suits would be filed.

On the other hand, these very reasons can be considered to justify a (b)(1) class action on the alternative rationale that an individual injunctive suit would be practically dispositive of the interests of the consumer class. ${ }^{12}$ This rationale is most pertinent where one of several persons is pressing a claim against a limited fund; however, the Advisory Committee's Notes to new Rule 23 make clear that an individual suit for injunctive relief which affects a defendant's capacity to deal. with other members of a group also is sufficient. ${ }^{113}$ Insofar as a consumer class action under the Uniform Act is concerned, the argument would be that a (b)(l) class action is justified by the probability that the first individual suit would discourage similar suits by other consumers, and by the probability that any subsequent decrees would mirror the decree obtained in the first individual action.

New Rule 23(b)(2) authorizes a class action wherever "the party opposing the class has acted or refused to act on grounds generally applicable to the class, thereby making appropriate final injunctive relief or corresponding declaratory relief with respect to the class as a

\footnotetext{
i" See, e.g., Peoplev. National Research Co., 201 Cal. App. 2d 765, 20 Cal. Rptr. 516 (1962).

112 Fed. R. Civ. P. 23(b)(1)(B).

113 "Similar problems, however, can arise in the absence of a fund either present or potential. A negative or mandatory injunction secured by one of a numerous class may disable the opposing party from performing claimed duties toward the other members of the class or materially affect his ability to do so." 39 F.R.D. 69, $101-02$ (1966) (Advisory Committee's Note to new Rule 23(b)(1)(B)).

The Advisory Committee on Civil Rules was appointed in 1960 by Chief Justice Warren and charged with advising the Judicial Conference of the United States concerning the need for revision of the Federal Rules. Announcement of the Chief Justice of the United Statcs Supreme Court, reproduced in 1966 Federal Procedure vii-ix (West 1966). The Committce's recommendations, including its explanatory notes, were approved by the United States Supreme Court and transmitted to Congress under the Rules Enabling Act, 28 U.S.C. $\$ 2072$ (1964); 39 F.R.D. 69 (1966). The Advisory Committee's Notes, therefore, constitute highly signifieant commentaries on the scope of the new rules.
} 
whole . . . ."1s The Advisory Committee's Note confirms the implition of the text of the rule that a (b)(2) class action "does not extend to cases in which the appropriate final relief relates exclusively or predominantly to money damages." 115

A consumer class action under the Uniform Act can fall squarely within the terms of new Rule 23(b)(2). A merchant who has standardized his deceptive schemes attempts to mistreat groups of his customers in the same way, ${ }^{116}$ and the Uniform Act makes available injunctive relief against such conduct. The attorneys' fees provision of the Uniform Act does not preclude (b)(2) class action treatment because the allowance of attorneys' fees is not automatic. ${ }^{17}$ Furthermore, computation of the fees allowable to the attorneys for the class representatives is not comparable to computation of the individual damages of every member of the class. While the latter computation can make class action treatment unmanageable, ${ }^{118}$ the former computation is far simpler ${ }^{119}$ and should not be considered to bar (b)(2) class action treatment.

Finally, new Rule 23(b)(3) permits a class action where "the court finds that the questions of law or fact common to the members of the class predominate over any questions affecting only individual members, and that a class action is superior to other available methods for the fair and efficient adjudication of the controversy." 120

"14 FED. R. CIV. P. 23(b)(2). New Rule 23(b)(2) is a response to the number of civil rights class actions that have been filed in recent years. Kaplan, Continuing Work of the Civil Committee: 1966 Amendments of the Federal Rules of Civil Procedure (I), 81 HARv. L. Rev. 356, 389 (1967). However, the Advisory Committee's Note states flatly that "Subdivision (b)(2) is not limited to civil-rights cases." 39 F.R.D. 69, 102 (1966).

1139 F.R.D. 69, 102 (1966).

${ }^{116}$ See, e.g., People v. Glubo, 5 N.Y.2d 461, 158 N.E.2d 699, 186 N.Y.S.2d 26 (1959); Robnet v. Miller, 105 Ohio App. 536, 152 N.E.2d 763 (1957).

"' UNIFORM ACT $\S 3(\mathrm{~b})$. But see notes 53-57 supra and accompanying text.

1" See School Dist. v. Harper \& Row Publishers, Inc., 267 F. Supp. 1001 (E.D. Pa. 1967); Comment, Litigating the Antitrust Conspiracy Under Amended Rule 23: Siegel v. Chicken Delight, Inc. and School District v. Harper \& Row Publishers, Inc., 54 VA. L. REv. 314, 318-20 (1968).

"There has been extensive experience in computing attorneys' fees under $\S 4$ of the Clayton Act, 15 U.S.C. $\S 15$ (1963), which permits recovery of attorneys' fees by successful antitrust treble-damage plaintiffs. Among the faetors considered are time spent, skill and standing in the Bar, customary charges for similar work, and whether the case was ordinary or extraordinary. See generally Note, The Nature of a "Reasonable Attorney's Fee" in Private Antitrust Litigation, 1966 W WSH. U.L.Q. 102. A number of other instances in which attorneys' fees are recoverable are recorded in Stoebuck, Counsel Fees Included in Costs: A Logical Development, 38 U. Colo. L. Rev. 202, 207-II (1966).

${ }^{120}$ Fed. R. Civ. P. 23(b)(3). 
These elements could be met by a consumer class action under the Uniform Act. Whether a particular merchant is engaging in a deceptive trade practice, whether consumers are likely to be damaged by the deceptive trade practice, and whether the court should exercise its discretion to grant an injunction and attorneys' fees are issues in which many customers of the merchant could have a common interest. ${ }^{21}$ Moreover, where a deceptive trade practice injures enough consumers to make a class action possible, such an action is generally preferable to individual litigation as a technique for regulating the practice. Indeed, as a practical matter, there may be no individual litigation. The Uniform Act's omission of a damage remedy reduces the likelihood that individual consumers will seek injunctive relief without the cost-sharing advantages of a class action..$^{122}$

It is not surprising that a consumer class action under the Uniform Act might be treated as either a (b)(I), (b)(2), or (b)(3) class action. Any scheme of classification involves line drawing and occasional hard choices. Furthermore, the general requirements in new Rule 23(a) that all class actions must involve common questions of law or fact and that representatives of the class must have typical claims or defenses ${ }^{123}$ mean that (b)(I) and (b)(2) class actions are, in effect, special cases of (b)(3) common-question class actions. ${ }^{124}$ Thus, one might infer that the categorization of a class action under a particular subsection of new Rule 23 is of little moment.

However, new Rule 23 indicates on its face that proper classification is important. With respect to (b)(3) class actions alone, new Rule 23(c)(2) requires the court to direct the best notice of the action which is practicable, including individual notice to all absentees

${ }^{121}$ Cf. Grand Rapids Furniture Co. v. Grand Rapids Furniture Co., 127 F.2d 245, 252 (7th Cir. 1942), cert. denied, 321 U.S. 771 (1944); California Apparel Creators v. Wieder, Inc., 162 F.2d 893, 902 (2d Cir.) (L. Hand, J., dissenting), cert. denied. 332 U.S. 816 (1947).

122 When an irate customer sued the Los Angeles Yellow Cab Company on behalf of himself and all other customers who had been overcharged within the period of the statute of limitations, the Supreme Court of California observed that without the class action the defendant probably would never be made to answer for its alleged wrongs. Daar v. Yellow Cab Co., 67 Cal. 2d 695, 715, 433 P.2d 732, 746, 63 Cal. Rptr. 724, 733 (1967) (In Bank).

Policing of deceptive trade practices by the Federal Trade Commission and various state consumer fraud bureaus is an alternative to a (b)(3) class action. However, this approach would make relief dependent upon the ebb and flow of public budgets and staffs. Professor Starrs has stated that "the courts could take judicial notice of the present inability of the F.T.C., consumer fraud bureaus, and offices of the attorneys general of the various states to cope with the everpyramiding evidence of fraud in more and more industries." Starrs, supra note 82, at 98.

${ }^{123}$ Fed. R. Civ. P. 23(a)(2), (3).

${ }^{24}$ Note, Proposed Rule 23: Class Actions Reclassified, 51 VA. L. REv. 629, 662 (1965). 
who can be identified with reasonable effort. ${ }^{125}$ The notice must advise each absentee that the court will exclude him from the class if he so requests by a specified date, that absentees who do not request exclusion will be bound by the judgment in the class action, and that any absentee who does not request exclusion may enter an appearance in the class action through his own counsel. ${ }^{26}$ The res judicata effect of a (b)(3) class action is, of course, impaired to the extent that the members of the class respond to (c)(2) notice by excluding themselves from the class. Furthermore, where a class is sizeable, the burden and expense involved in (c)(2) notice may make a class action impracticable. ${ }^{127}$

Mandatory (c)(2) notice and the privilege of self-exclusion are not made features of (b)(1) or (b)(2) class actions by new Rule 23. These latter actions accordingly have the potential of being more effective and less awkward than their (b)(3) counterparts. ${ }^{123}$ However, the recent Second Circuit decision in Eisen $v$. C'arlisle \& Jacquelin ${ }^{139}$ suggests that (b)(1) and (b)(2) class actions involve a notice requirement which parallels that in (b)(3) class actions.

Eisen was a class action against the two major odd-lot dealers on the New York Stock Exchange, and the Stock Exchange itself. ${ }^{130}$ The complaint alleged that the defendant dealers had combined and conspired to monopolize odd-lot trading and had fixed the odd-lot commission differential at an excessive amount in violation of the Sherman Antitrust Act. ${ }^{131}$ The Stock Exchange was charged with failure to protect odd-lot investors through the adoption of rules

${ }^{125}$ FED. R. CIV. P. 23(c)(2). But see id. 23(d)(2) which authorizes a court to require notice to non-party members of a class wherever this is necessary for the protection of the absentees or for the fair conduct of the action.

${ }^{126} \operatorname{Id} .23(\mathrm{c})(2)$.

${ }^{127}$ Eisen v. Carlisle \& Jacquelin, 391 F.2d 555, 568-70 (2d Cir. 1968); School District v. Harper \& Row Publishers, Inc., 267 F. Supp. 1001, 1004-05 (E.D. Pa. 1967). It is presently an open question whether the court or the litigants should dispatch the notice. Compare Kaplan, supra note 114, at 398 \& n.157 with Proceedings of the Twenty-Ninth Annual Judicial Conference, Third Judicial Circuit of the United States, 42 F.R.D. 437, $565-66$ (1966) (remarks of Professor Charles Wright).

${ }^{125}$ Professor Wright has speculated, "I would guess that we will not see in the immediate future very many actions which the court permits to be maintained as (b)(3) class actions ... Proceedings, supra note 127, at 567 .

129391 F.2d 555 (2d Cir. 1968).

130 "Odd-lot" stock exchange transactions involve units of less than 100 shares. They are handled by special odd-lot dealers who buy and sell for their own accounts as principals. $I d$. at 559.

13. 15 U.S.C. $\$ \$ 1 \& 2$ (1964). 
under the Securities Exchange Act of 1934..$^{132}$ The sole plaintiff, whose actual damages were estimated to be $\$ 70,{ }^{133}$ sought to recover damages on behalf of himself and an estimated $3,750,000$ other buyers and sellers of odd-lots from 1960 to $1966 .{ }^{134}$ However, the trial court dismissed the class action aspects of the case, ${ }^{135}$ maintaining that $\mathrm{Mr}$. Eisen had failed to demonstrate that questions common to the class predominated over questions pertaining primarily to individual class members and that he could adequately represent the interests of the class. Three reasons were given for the latter holding: (1) Mr. Eisen had not satisfied the court that his damage claims were typical of the damage claims of the class; (2) Mr. Eisen's interest was so miniscule as to preclude adequate representation of the class; and (3) Mr. Eisen could not practicably give the (c)(2) notice that was required in a (b)(3) class action. ${ }^{136}$

Because the trial court's ruling would, for all practical purposes, terminate Mr. Eisen's suit, the decision was held to be immediately appealable. ${ }^{137}$ The Second Circuit, while agreeing that a (b)(3) class action which required (c)(2) notice was involved, ${ }^{138}$ reversed the dismissal of the class action ${ }^{139}$ and held that the trial judge had misapplied new Rule 23. Initially, the Second Circuit found that the class had a common interest in the legality of the odd-lot differential and that Mr. Eisen's claim involved this interest. ${ }^{140}$ Moreover, quantitative representation, in the sense of high percentage of the members of a class joining in an action, was held not to be essential to adequate representation of a class. In a noncollusive suit, one litigant with competent counsel and typical claims was found prima facie able to represent adequately a large class. ${ }^{1+1}$ Finally, the appellate court held that the feasibility of judicial administration, the mechanics of (c)(2) notice, and the sufficiency of representation were not to be determined summarily. The case was remanded for an evidentiary hearing on such issues, with or without discovery proceedings. ${ }^{142}$

\footnotetext{
${ }^{132} I d . \$ \$ 78 \mathrm{f}(\mathrm{b}) \&$ (d), $78 \mathrm{~s}(\mathrm{a})$.

${ }^{133}$ Eisen v. Carlisle \& Jacquelin, 391 F.2d 555, 564 n.8 (2d Cir. 1968).

${ }^{13}$ The estimate was made by the defendants and not disputed by the plaintiff. Id. at 561-62.

${ }^{135} 41$ F.R.D. 147 (S.D.N.Y. 1966).

${ }^{136} I d$. at $150-52$.

${ }^{137} 370$ F.2d 119 (2d Cir. 1966), cert. denied, 386 U.S. 1035 (1968).

is 39 I F.2d 555, 564-65 (2d Cir. 1968).

139 Id. at 570 .

${ }^{140} I d$. at 561-62.

${ }^{141} I d$. at $562-63$.

${ }^{142}$ Id. at 563-70. Eisen, the first full-dress court of appeals analysis of new Rule 23 , id. at 560 ,
} 
In addition to the holdings regarding (b)(3) actions, Eisen contains some significant dicta with respect to (b)(I) and (b)(2) class actions. The plaintiff in Eisen argued that his suit could be considered a (b)(1) or a (b)(2) class action as well as a (b)(3) class action and that notice to the members of the class was not mandatory with respect to (b)(1) or (b)(2) actions. ${ }^{143}$ The Second Circuit dismissed the propriety of (b)(1) or (b)(2) classification of the action but, nevertheless, went on to deal with the notice issue. The court stated:

[W] hold that notice is required as a matter of due process in all representative actions, and $23(\mathrm{c})(2)$ merely requires a particularized form of notice in 23(b)(3) actions. Mullane v. Central Hanover Bank and Trust Co., 339 U.S. 306, 70 S. Ct. 652, 94 L. Ed. 865 (1950). Advisory Committee's Note at 107. ${ }^{144}$

This dictum is overbroad. The Mullane case held that "notice reasonably calculated, under all the circumstances, to apprise interested parties of the pendency of the action and afford them an opportunity to present their objections" ${ }^{145}$ is an element of due process only where due process requires that notice be given to persons whose interests are affected by a judicial proceeding. ${ }^{146}$ However, the Supreme Court has never determined that due process requires that notice of a class action be given to all of the members of the class. In the leading case of Hansberry v. Lee, ${ }^{147}$ the Court stressed adequacy of representation by the class representatives, rather than the dispatch of notice of the action to the members of the class, as the principal requisite of due process. ${ }^{145}$

The emphasis on adequacy of representation in Hansberry makes sense. As Professor Chafee pointed out years ago, notice does not

was decided by the prestigious Second Circuit. The case will assuredly be influential. See Hohmann v. Packard Instruments Co., 399 F.2d 711 (7th Cir. 1968); Minnesota v. United States Steel Corp., 44 F.R.D. 559 (D. Minn. 1968).

it3 391 F.2d at 564 (2d Cir. 1968).

${ }^{1+4}$ Id. at 564-65.

iss Mullane v. Central Hanover Bank \& Trust Co., 339 U.S. 306, 314 (1950).

its See id.; Fraser, Jurisdiction by Necessity-An Analysis of the Mullane Case, $100 \mathrm{U}$. PA. L. Rev. 305, 316-19 (1951).

147311 U.S. 32 (1940).

148 "It is familiar doctrine' of the federal courts that members of a class not present as parties to the litigation may be bound by the judgment where they are in fact adequately represented by parties who are present . . . 311 U.S. at 42-43. The most recent Supreme Court case to consider the question stresses the adequacy of representation aspect of Hansberry. See American Federation of Musicians v. Carroll, 391 U.S. 99, 103 n.4 (1968). Commentators taking the position that notice is not an inflexible constitutional requirement of a binding class action include: Z. Chafee, Some Problems of Equity 275-77 (1950); N.Y. Judicial Council 18th ANN. ReP. 242-44 (1952); Note, Proposed Rule 23: Class Actions Reclassified, 51 VA. L. Rev. 
necessarily notify. ${ }^{149}$ As Hansberry implies, an identity of interests between class representatives and the class represented can be more productive of adequate representation than the dispatch of notice to the class. ${ }^{150}$ On the other hand, notice of a class action can help to ensure adequate representation by providing an opportunity for the class to register objections to the representation. ${ }^{\text {st }}$ This latter type of notice, however, would be a more flexible requirement than the Mullane-type notice apparently contemplated by the Eisen dictum.

ln some cases, the cohesiveness and internal communications system of a class will render notice of an action superfluous as a test for adequacy of representation. ${ }^{152}$ For example, this will often be true in civil rights class actions, ${ }^{153}$ and in cases where the officers of an unincorporated association, such as a labor union, sue or are sued in a representative capacity. ${ }^{154}$ Moreover, notice which is intended to test the adequacy of representation would not have to be sent to all members of the class in order to bind the class. If notice is sent to an adequate number of randomly-selected class members, it is probable that the response will be representative of the class as a whole. ${ }^{155}$ Conversely, if receipt of the Mullane type notice is a predicate to being bound by the result of a class action, every known class member must be sent individual notice in order for the judgment in the action to preclude all further litigation. ${ }^{156}$

Notwithstanding the Eisen dictum, the text and notes to new Rule 23 are congruent with the view that the use of notice to test adequacy of representation in (b)(1) and (b)(2) class actions is discretionary and can be selective. New Rule 23(d) states:

629, 636-40 (1965). Contra, Keeffe, Levy \& Donovan, Lee Defeats Ben Hur, 33 CoRNell L.Q. 327, 337-39 (1948); Note, Federal Class Actioins: A Suggested Revision of Rule 23, 46 Colum.

L. Rev. 818, 833-36 (1946).

is Z. CHAFEE, supra note 148, at 276-77.

${ }^{130}$ See id.

ist Kaplan, supra note 114, 379-80.

iss Id.; see 39 F.R.D. 69, 106 (1966) (Advisory Committee's Note to new Rule 23(d)(2)).

${ }^{133}$ See Washington v. Lee, 263 F. Supp. 327 (N.D. Ala. 1966), aff d per curiam, 390 U.S. 333 (1968) (action for declaratory and injunctive relief with respect to a segregated penal system).

${ }^{i s 4}$ A merican Airlines, Inc. v. Transport Workers Union, 44 F.R.D. 47 (N.D. Okla. 1968). New Rule 23.2 deals separately with actions relating to unincorporated associations but reiterates the essentials of new Rule 23, FED. R. CIV. P. 23:2.

iss Note, Binding Effect of Class Actions, 67 Harv. L. Rev. 1059, 1064 (1954); cf. Mullane v. Central Hanover Bank \& Trust Co., 339 U.S. 306, 318-19 (1950). Statistical sampling techniques could prove useful on this score.

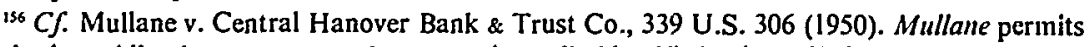
notiee by publication to persons who cannot be easily identified. Id. at 317-18. 
In the conduct of actions to which this rule applies, the court may make appropriate orders: . . . (2) requiring, for the protection of the members of the class or otherwise for the fair conduct of the action, that notice be given in such manner as the court may direct to some or all of the members of any step in the action, or of the proposed extent of the judgment, or of the opportunity of members to signify whether they consider the representation fair and adequate, to intervene and present claims or defenses, or otherwise to come into the action. ${ }^{157}$

Although notice concerning adequacy of representation is described as only one of several possible types of notice by the new rule, all of the kinds of notice specified relate to adequacy of representation and provide an opportunity to raise that issue. Accordingly it is highly significant that the Advisory Committee's Notes make clear that a trial judge has discretion with respect to utilization of (d)(2) notice and that such notice is more pertinent to (b)(3), than to (b)(l) or (b)(2) class actions. ${ }^{158}$

Therefore, it seems apparent that neither the Constitution nor new Rule 23 itself require mandatory notice of pending (b)(1) and (b)(2) class actions to all known members of the class. This is fortunate for, where there is a large consumer class and the individual stakes are relatively small, the expense of providing class-wide notice could effectively preclude litigation. ${ }^{159}$ Furthermore, many consumer class actions may not require even selective notice to test adequacy of representation. Substantial numbers of the consumer class may belong to the same consumer cooperative or live in the same neighborhood so that intra-group channels of communication can be relied upon. Even in the absence of such modes of communication, a defendant-merchant's conduct may be so opprobrious and the consumer class' common interest in relief so clear that selective notice can be safely dispensed without jeopardizing adequate representation of individual consumer interests. ${ }^{160}$ Dispensing with notice

ist 39 F.R.D. 69, 97 (1966).

138 "Subdivision (d)(2) does not require notice at any stage, but rather calls attention to its availability and invokes the court's discretion. In the degree that there is cohesiveness or unity in the class and the representation is effective, the need for notice to the class will tend toward a minimum. These indicators suggest that notice under subdivision (d)(2) may be particularly useful and advisable in certain class actions maintained under subdivision (b)(3) . . " 39 F.R.D. at 106 (Advisory Committee's Note to new Rule 23(d)(2))

${ }^{139}$ See Daar v. Yellow Cab. Co., 67 Cal. 2d 695, 433 P.2d 732; 63 Cal. Rptr. 724 (1967) (In Bank).

${ }^{160}$ See Note, Proposed Rule 23: Class Actions Reclassified, 51 VA. L. Rev. 629, 638-40 (1965). 
of an action does not mean that a resultant decree will never be brought to the attention of a consumer class. The decree itself can require that the defendant take reasonable steps to notify his customers of a court-ordered change in marketing methods. ${ }^{161}$

When the Eisen dictum concerning notice requirements in (b)(1) and (b)(2) class actions is put into perspective, it is clear that the (b)(1) and (b)(2) class actions are less cumbersome and expensive than (b)(3) class actions. Mandatory notice to the entire class is required in (b)(3) class actions alone.$^{162}$ Consequently, the determination as to whether a consumer class action is being maintained under subsection (b)(1), (b)(2), or (b)(3) takes on increased significance. The problem of classification is naturally complicated by the fact that a consumer class action can satisfy the criteria of all three subsections.

A similar classification problem was discussed in Van Gemert $v$. Boeing $\mathrm{Co} .^{163}$ an action by the holders of convertible debentures against the issuer of the debentures. While recognizing that the action technically qualified under the provisions of all three subsections, the court declined to treat the suit as a $23(\mathrm{~b})(3)$ action reasoning that "to do so would defeat the very objectives intended to be achicved by Rule 23(b)(1) and (2)."164

The Van Gemert court correctly concluded that a class action maintainable as a (b)(1) or (b)(2) class action should not ordinarily be treated as a (b)(3) class action and thus subject to the (c)(2) self-exclusion procedure. The self-exclusion procedure was primarily intended to accommodate a class member's nonconstitutional interest in pursuing individual rather than group litigation where the reasons for class action treatment are not compelling. Thus, the Advisory Committee's Note to new Rule 23(b)(3) describes (b)(3) class actions as involving situations in which "class action treatment is not as clearly called for as in those described above. ..."165 The text of the rule and Advisory Committee's Note also indicate that the major factor behind the provision for self-exclusion was concern for a class member's interest in personally controlling his own lawsuit. ${ }^{166}$

\footnotetext{
${ }^{161} C f$. Crossbow, Inc. v. Glovemakers, Inc., 265 F. Supp. 202 (N.D. Ill. 1967).

${ }^{162}$ FED. R. CIV. P. 23(c)(2).

${ }^{163} 259$ F. Supp. 125 (S.D.N.Y. 1966).

${ }^{164} I d$. at $\mathrm{I} 30$.

165 39 F.R.D. 69, 102 (1966) (Advisory Committee's Note to New Rule 23(b)(3)).

${ }^{166} \mathrm{New}$ Rule 23(b)(3) requires a court to consider the following factors in determining whether a (b)(3) class action is superior to other methods of resolving a controversy: "(A) the interest of
} 
Although Van Gemert evinces a sound principle, its precise rationale is not pertinent to consumer class actions under the Uniform Act. Consumers notified of a class action for an injunction are more likely to remain apathetic than to demand either exclusion from, or active inclusion in the lawsuit. ${ }^{167}$ On the other hand, avoidance of mandatory (c)(2) notice where it is unnecessary also justifies preference for a (b)(1) or a (b)(2) classification. The expense, bother, and potential use of the notice to engage in undesirable solicitation of claims $^{168}$ justify dispensing with the notice requirement wherever possible.

However, the court must take care that members of the class are not prejudiced by $(b)(1)$ or (b)(2) class-action characterization. Prejudice can be avoided by invoking new Rule 23(c)(4)(A) which permits a court to limit the scope of a class action to specific issues. ${ }^{169}$ Thus, designation of a consumer class action under the Uniform Act as a (b)(l) or a (b)(2) action should be accompanied by an exclusion from the class action of issues concerning the contract or tort damage liability of the defendant-merchant to individual members of the consumer class. Ascertaining the existence and amount of this damage liability requires a painstaking evaluation of individual transactions which is not requisite to establishing a violation of the Uniform Act. Moreover, in order to ensure adequate representation,

members of the class in individually controlling the prosecution or defense of separate actions; (B) the extent and nature of any litigation concerning the controversy already commenced by or against members of the class; (C) the desirability or undesirability of concentrating the litigation of the claims in the particular forum; (D) the difficulties likely to be encountered in the management of a class action." FED. R. Civ. P. 23(b)(3). See also 39 F.R.D. 69, 103-04 (1966) (Advisory Committee's Notes to New Rule 23(b)(3) and 23(c)(2)). A California State Bar Association Committee has maintained that the self-exclusion provision does not adequately safeguard the interest in individual control of litigation. Report of the Carlifornia State Bar Committee on Federal Courts, 37 F.R.D. 75, 76-77, 81-82 (1965). On the other hand several commentators have argued that the new rule errs in not placing limitations upon the privilege of self-exclusion. Note, Revised Federal Rule 23. Class Actions: Surviving Difficulties and New Problems Require Further Amendment, 52 MinN. L. Rev. 509, 524-27 (1967); Note, Proposed Rule 23: Class Actions Reclassified, 51 VA. L. Rev. 629, 652-55 (1965).

${ }^{167}$ New Rule 23(c)(2) provides that silence following dispatch of (c)(2) notice results in inclusion in the class action rather than exclusion from the class action. This equation of silence with consent was made in recognition of the general apathy of "small guys" insofar as litigation is concerned. Frankel, Amended Rule 23 From a Judge's Point of View, 32 Antrrrust L.J. 295, 299-300 (1966); Kaplan, supra note 114, at 397-98.

${ }^{168}$ The Advisory Committee's Note warns against this possible misuse of notice. 39 F.R.D. 69, 107 (1966) (Advisory Committee's Note to New Rule 23(d)). See also Comment, Recovery of Damages in Class Actions, 32 U. CHI. L. REV. 768, 779-82 (1965).

169 "When appropriate $(A)$ an action may be brought or maintained as a class action with respect to particular issues . .. ." FED. R. CIv. P. 23(c)(4)(A). 
members of a class who have substantial damage claims should be entitled to notice of any class action which will adjudicate their claims, and there should be a high degree of confidence in the class representatives. ${ }^{170}$ The presence of substantial individual damage claims also raises the possibility of a preference for individual litigation. Where a court believes that a consumer class action embracing contract and tort claims, as well as claims under the Uniform Act, is superior to other methods for the fair and efficient adjudication of a controversy, (b)(3) classification is preferable unless it is clear that only minimal damage claims are involved. The privilege of self-exclusion and (c)(2) notice are most meaningful where substantial damage claims are possible. The Advisory Committee's Note, for example, suggests application of the (b)(3) procedure to fraud cases involving damage claims. ${ }^{171}$ Nonetheless, there will be many instances in which (b)(3) classification can be avoided under new Rule 23 through limitation of a class action to a claim for injunctive relief.

\section{FORMER RULE 23}

Because former Rule 23 has been incorporated into the procedure of a number of states, analysis of the feasibility of bringing a consumer class action under the Uniform Act cannot end with new Rule 23. Precedents under former Rule 23 will continue to be given weight in states with rules derived from the former federal rule.

Former Rule 23 initially sets forth the fundamental "large class" and "adequate representation" prerequisites to a class action. ${ }^{172}$ These criteria have already been discussed in connection with new Rule $23 .{ }^{173}$ However, it should be pointed out that Eisen's concept of adequate representation is apt to be influential under the old rule as well as under the new rule. ${ }^{74}$

Former Rule 23 distinguished between true, hybrid, and spurious class actions depending on whether the right sought to be enforced for

\footnotetext{
${ }^{170} C f$. Hansberry v. Lee, 311 U.S. 32 (1940).

173 39 F.R.D. 69, 102-03 (1966) (Advisory Committee's Note to New Rule 23(b)(3) ).

12 FED. R. CIV. P. 23(a).

${ }^{173}$ See notes 90-95, 99-105 supra and accompanying text.

${ }^{173}$ The notion that qualitative representation was more important than quantitive representation was recognized under former Rule 23. Compare Waybright v. Columbian Mutual Life Ins. Co., 30 F. Supp. 885, 888 (IV.D. Tenn. 1939), aff d on other grounds, 122 F.2d 245 (6th Cir. 1941) and 2 W. Barron \& A. Holtzoff, Federal Practice and Procedure, $\$ 567$ (C. Wright Rev. Ed. 1961) with note 107 supra and accompanying text.
} 
or against the class was (1) joint, common, or secondary; (2) several, where the claim might or did affect specific property; or (3) several, where the claim involved a common question of law or fact and common relief was sought. ${ }^{175}$ The judgment in a true class action was generally considered to bind all the members of the class, the judgment in a hybrid class action to bind all the members of the class with respect to the specific property at issue, and the judgment in a spurious class action to bind those members of the class who were parties to the action. ${ }^{176}$

Insofar as consumers are concerned, the classification of a consumer class action for an injunction makes little difference under former Rule 23. There are several decisions which indicate that even an injunction granted in a spurious class action can protect nonparty members of the class, ${ }^{177}$ and former Rule 23 does not require notice of the initiation of any type of class action. ${ }^{178}$ However, it is advantageous from a defendant-merchant's standpoint, especially where he has a good defense, for a class action to be considered either true or hybrid. Judgments in class actions falling within these categories bind the entire class and provide a res judicata defense to the merchant in subsequent, duplicative litigation. ${ }^{179}$

A practitioner of deceptive trade practices may take consumers' money, but he does not ordinarily jeopardize consumers' interests in the same specific property. Hence, a consumer class action under the Uniform Act is not likely to be considered a "hybrid" class action. ${ }^{180}$

${ }^{175}$ FED. R. CIv. P. 23(a)(1)-(3). The appellations derive from Professor Moore who played an active part in the drafting of former Rule 23.3A J. MoORE, Federal. PRACTICE $\uparrow$ 23.08-.10 (2d ed. 1968).

${ }^{176}$ E.g., Dickinson v. Burnham, 197 F.2d 973, 978-79 (2d Cir.), cert. denied, 344 U.S. 875 (1952) (dictum); C. WRIGHT, FedERAL, CourTs 271 (1963). These conclusions as to res judicata effect also derive from Professor Moore.

${ }^{17}$ E.g., Frasier v. Board of Trustees, 134 F. Supp. 589 (M.D.N.C. 1955), aff d per curiam, 350 U.S. 979 (1956); National Hairdressers' and Cosmetologists' Association v. Philad Co., 41 F. Supp. 701 (D. Del. 1941), aff d per curiam, 129 F.2d 1020 (3d Cir. 1942); Developments in the Law-Multiparty Litigation in the Federal Courts, 71 HARv. L. REv. 874, 935-36 (1958).

${ }^{178}$ FED. R. Civ. P. 23. Rule 23(c) does require notice to the class of the dismissal or compromise of a true class action.

179 3A J. MoORE, supra note 175, at 123.11 . Section 3(b) of the Uniform Act provides an additional deterrent to unnecessary suits. Section 3(b) allows the award of attorneys' fees to a defendant where "the party complaining of a deceptive trade practice has brought an action which he knew to be groundless." UNIFORM ACT \& 3(b)(l).

${ }^{180}$ A hybrid class action exists where the right sought to be enforced for or against the class is "several, and the object of the action is the adjudication of claims which do or may affect specific property involved in the action . . . " FED. R. CIV. P. 23(a)(2). 
The choice is accordingly between treatment as a true class action, in which the result would be res judicata with respect to the claims of the entire class, and treatment as a spurious class action, in which the result would be res judicata only as to the claims of the members of the class who were parties to the action. The case of Grand Rapids Furniture Co. v. Grand Rapids Furniture Co. ${ }^{181}$ supports the trueaction classification.

In Grand Rapids, the Furniture Manufacturers Association of Grand Rapids and twenty-four Grand Rapids furniture manufacturers sued in federal court to enjoin a Chicago retailer and its incorporators from using "Grand Rapids" as a trade name. The theory of the complaint was that the defendants were deliberately creating the false impression that they were affiliated with a Grand Rapids furniture manufacturer and could offer bargain prices on Grand Rapids furniture; whereas, in fact, the defendants sold inferior furniture that was not manufactured in Grand Rapids. ${ }^{182}$ The trial judge granted a preliminary injunction and the defendant-retailer appealed on the ground that the plaintiffs' individual claims did not exceed the court's jurisdictional amount. However, the Seventh Circuit held that there was diversity jurisdiction because the plaintiffs' claims could be aggregated in order to attain the jurisdictional amount. The basis for aggregation was the nature of the claims:

In the instant case we have a common cause of action, based upon the same acts of the defendants. The plaintiffs have an undivided interest, though separable as between themselves, and the amount of their joint claim will be the test of jurisdiction . . . . The relief demanded is identical. If any one plaintiff should in a single suit recover on the demand here made by it or him, that judgment would of itself immediately furnish all the relief which the other plaintiffs are here demanding for themselves, except as to the amount of damages. That phase of this case is purely incidental, as all the appellees and the appellant respectively aver and admit that each of the defendants is financially irresponsible. ${ }^{183}$

Grand Rapids suggests that a consumer class action for an injunction should be considered a true class action under former Rule

181 127 F.2d 245 (7th Cir. 1942). Grand Rapids tcchnically involved voluntary multiplc joinder of parties rather than a class action. However, its holding is also pertinent to class actions. The Grand Rapids court itself commented: "True, the instant suit is not a class suit by representation, nevertheless, we think it is a class suit." Id. at 251 .

${ }^{182}$ Id. at 246-47.

${ }^{183}$ Id. at 252. 
23. A true class action can exist where class members have "common" as well as "joint" rights, ${ }^{184}$ and Grand Rapids recognizes that persons likely to be damaged by deceptive practices have a common interest in obtaining injunctive relief. ${ }^{185}$ This is true whether the persons suing are consumers or businessmen. Additional support for a true-class-action categorization can be found in the holding of Grand Rapids that the interests of the plaintiff-manufacturers were sufficiently intertwined to permit aggregation of their claims for jurisdictional purposes. In determining whether aggregation was permissible when former Rule 23 was in force, the federal courts utilized the distinctions between true, hybrid, and spurious class actions in construing their jurisdictional statutes, and only allowed aggregation where the interests of the class were joint or common rather than several. ${ }^{186}$ Finally, new Rule 23 permits a class action for an injunction to be treated as a binding class action, ${ }^{187}$ one of the principal consequences of a true-class-action categorization. ${ }^{188}$

Pursuant to the Grand Rapids principle, a consumer class action for an injunction can be considered a true class action under former Rule 23. However, as under new Rule 23, attention must be given to the interests of consumers who can claim substantial contract or tort damages for the conduct which violates the Uniform Act. The true class action should ordinarily be confined to determining whether the defendant has engaged in a deceptive trade practice and whether the consumer-class is entitled to an injunction and an award of attorneys'

${ }^{184}$ FED. R. CIv. P. 23(a)(1), Appendix, 28 U.S.C. at 6101 (1964). What constitutes a "common" right is to some extent a matter of conjecture. "Perhaps 1 am color-blind with respect to class suits, but $I$ often have as much perplexity in telling a 'common' right from a 'several' right as in deciding whether some ties and dresses are green or blue." Z. CHAFEE, supra note 148 , at 257.

${ }^{185}$ See Grand Rapids Furniture Co. v. Grand Rapids Furniture Co., 127 F.2d 245, 252 (7th Cir. 1942); 2 W. BARRon \& A. Holtzoff, supra note 174, $\$ 562.1$ at 267 \& n. 24. See also Pillsbury-IVashburn Flour Mills Co. v. Eagle, 86 F. 608, 629, 630 (7tb Cir. 1898), cert. denied, 173 U.S. 703 (1899).

${ }^{186}$ Giesecke v. Denver Tramway Corp., 81 F. Supp. 957 (D. Del. 1949) (citing numerous cases); 1 J. Moore, supra note 175, at If 0.97[5] (2d ed. 1964); Cohn, Problems in Establishing Federal Jurisdiction Over an Unincorporated Labor Union, 47 GEo. L.J. 491,525 (1959). Grand Rapids did not apply these distinctions, because it was not a class action. However, the description of the plaintiffs' interests by the Grand Rapids court is congruent with the indicia of a true class action. See notes 175-76 supra and accompanying text.

1s' FED. R. CIv. P. 23(b)(2), (c)(3).

${ }^{188}$ The other major distinctions between true, hybrid, and spurious class actions related to nuances of federal jurisdiction which are not material in state courts. See C. WRIGHT, supra note 176, at 271-72. 
fees. ${ }^{189}$ Substantial individual contract or tort damage claims should either be excluded from the ambit of the class action or processed concurrently following notice to consumers of the opportunity to present their claims. In the event that a consumer class action is confined to a claim for injunctive relief under the Uniform Act, former Rule 23 does not require that notice be dispatched to the class except in the event of compromise or dismissal of the class action. ${ }^{190}$ Nor does the Constitution require notice in the absence of a question concerning the ability of the class representatives to represent the class. ${ }^{191}$

\section{CONCLUSION}

The Uniform Deceptive Trade Practices Act specifically proscribes a number of widespread deceptive practices, such as bait advertising, price misrepresentation, and covert substitution of goods. ${ }^{192}$ Moreover, section 2(a)(12) contains a general prohibition of "conduct which similarly creates a likelihood of confusion or of misunderstanding," 193 which is a vehicle for the importation of Federal Trade Commission precedents into the law of private deceptive trade practices. ${ }^{194}$ The sweep of the Uniform Act accords considerable significance to the issue of consumer standing to invoke its remedies. ${ }^{195}$

The tenor of the proceedings of the Commissioners on Uniform State Laws and the Official Prefatory Note to the Uniform Act, when

\footnotetext{
${ }^{189}$ Although former Rule 23, unlike new Rule 23, did not explicitly authorize a limited class action technique, a federal court had discretion to utilize this approach under former Rule 23. Dole, The Emergence of Deceptive Advertising as a Group Tort: A Possible Consequence of the 1966 Federal Rule Amendment With Respect to Class Actions, 62 Nw. U.L. REV. 661, $696-97$ (1967); Note, Federal Rules: Class Actions, 7 OKLA L. Rev. 472, 474-76 (1954). See Jinks v. Hodge, 11 F.R.D. 346 (E.D. Tenn. 1951), a case under former Rule 23 in which a federal district judge seemed to consider a class action to be a true class action solely with respeet to the demand for an injunction.

${ }^{390}$ Former Rule 23 required notice of compromise or dismissal only with respect to true class actions. FED. R. CIV. P. 23(c).

${ }^{191}$ See notes 148-61 supra and accompanying text.

192 Uniform Act $\$ \S 2(a)(1),(9),(10)$, and (11). See D. Caplovitz, The Poor Pay More, ch. 10 (1967) concerning the prevalence of these deceptive practices.

${ }^{193}$ UNIFORM ACT $\& 2(a)(12)$.

194 Dole, The Uniform Deceptive Trade Practices Act: Another Step Toward a National Law of Unfair Trade Practices, 51 MiNN, L. REv. 1005, 1038-41 (1967); cf. People v. National Research Co., 20I Cal. App. 2d 765, 20 Cal. Rptr. 516 (1962).

395 This is especially true in view of the deterrent effect of consumer-initiated litigation. $C \int$. National Conference on Law and Poverty, Conference Proceedings 12-14 (Washington, D.C., June 23-25, 1965) (remarks of Professor Allison Dunham).
} 
linked with the interest that consumers can have in continuing to deal with a merchant who has committed deceptive trade practices, support the conclusion that a consumer can be sufficiently "likely to be damaged" by a deceptive trade practice to have standing to sue under the Uniform Act. This individual consumer standing in turn provides the underpinning for consumer class actions that constitute an important mechanism for the suppression of widespread and systematic consumer deception. 
, 